Центр воєнно-стратегічних досліджень Національного університету оборони України імені Івана Черняховського, Київ

\title{
Аналіз регіональних воснно-політичних відносин за проблемою вирішення воснного конфлікту на сході України
}

Резюме. У статті автор аналізує трансформацію воєнно-політичних відносин, які виявлені у відкритому інформаційному просторі, в регіоні довкола України за проблемою вирішення конфлікту на ії сході.

Ключові слова: безпекове середовище; воєнно-політична обстановка; воєнно-політичні відносини; воєнна політика; воєнний конфлікт.

Постановка проблеми. У 2020 році почалась посилена пандемією коронавірусу світова фінансово-економічна криза, ознаки якої виявлялись досить давно [1]. Вона одразу призвела до різкого падіння фінансових i енергетичних ринків, відмови майже усіх держав від свободи руху людей i, головне, до гальмування економічних процесів. За станом на кінець березня 2020 року навіть у США очікувалось падіння ВВП до $34 \%$ у другому кварталі 2020 року порівняно 3 аналогічним кварталом тогоріччя [2]. Природно, такі фундаментальні зсуви неминуче потягнуть корекцію ставлення впливових держав до актуальних воєнно-політичних проблем в регіоні, однією з яких є проблема вирішення воєнного конфлікту на сході України. Практика показує, що в кризових ситуаціях підвищується можливість перенесення уваги до фінансово-економічних проблем, укладання сепаратних угод, розмін позиціями по різних проблемах. Унаслідок зміни інтересів та/або ї пріоритетності не виключаються корінні розвороти воєннополітичного курсу держав. Тому, для України вкрай важливо розуміти суть воєннополітичних відносин за проблемою вирішення конфлікту на сході, зокрема, для формування адекватної воєнної політики в умовах світу, який радикально змінюватиметься.

Аналіз останніх досліджень i публікацій. Стосовно аналізу збройної агресії РФ на сході України відомо багато наукових публікацій, наприклад [3, 4]. Але, на жаль нині відсутні наукові публікації, спрямовані на аналіз проблеми вирішення воєнного конфлікту на сході України 3 врахуванням позицій усіх залучених воєнно-політичних сил та в контексті їх можливих змін.

Мета статті полягає у дослідженні позицій воєнного-політичних сил по проблемі вирішення воєнного конфлікту на сході
України, які останнім часом були виявлені у відкритому інформаційному просторі, i виявленні ознак їх можливих змін. Лише максимальна адекватність оцінки зовнішнього безпекового середовища дасть змогу формувати реальну воєнну політику із захисту сталого поступального соціальноекономічного розвитку України.

Виклад основного матеріалу. Перша ознака зсуву ставлення провідних воєннополітичних сил до воєнного конфлікту на сході України з'явилася на початку 2019 року. Нею стало виключення 3 пріоритетів $\mathrm{OOH}$ питань вирішення цього конфлікту i постановка його Генсеком ООН в один ряд 3 іншими замороженими конфліктами [5]. Це може означати, що $\mathrm{OOH}$ не бачить можливості вирішення конфлікту, а жодна зі сторін у найближчий час не спроможна вирішити конфлікт на свою користь.

Окрім згаданого рішення ООН, про зміну ставлення впливових держав до конфлікту на сході України наочно свідчить також заява голови французької розвідки К. Гомара [6], що РФ ніколи не готувала військового вторгнення до України, а розвідка США давала неправдиві відомості про вторгнення армії РФ.

Певними маркерами зміни ставлення впливових держав до України та ії політики щодо вирішення конфлікту стала трансформація оцінок суспільно значимих трагічних подій. Перший такий маркер - тема катастрофи літака рейсу $\mathrm{MH}-17$, за якою почали з'являтись повідомлення про причетність до катастрофи США і України. Зокрема, лунали обвинувачення України у незакритті повітряного простору над зоною конфлікту, що призвело до катастрофи. Другій маркер - стрілянина на Майдані незалежності у 2014 році, вбивства активістів і бійців підрозділу “Беркут". Усупереч 
офіційної версії, що стрілянину організували прибічники екс-президента В. Януковича, іноземні ЗМІ почали висловлювати інші думки. Зокрема, говорилось про участь у стрілянині грузинських найманців, причетність до неї лідерів Майдану, ЦРУ та Агенції національної безпеки США. Тема вбивств на Майдані також стала використовуватись у внутрішній політичній боротьбі США. Зокрема, на каналі "One America News” було показано документальний фільм 3 обвинуваченнями лідерів Демократичної партії США у причетності до вбивств на Майдані [7].

3 іншого боку, аналіз інформаційних повідомлень ЗМІ свідчить, що РФ у проблемі значно зменшила активність і зайняла позицію очікування, роблячи акцент на розв'язанні власних соціально-економічних проблем. Посадові особи РФ і політичні аналітики, причетні до формування державної політики, переважно наголошували на неможливості швидкого вирішення конфлікту, завдяки його складного характеру. Утім РФ не залишала без контролю ситуацію на сході України i створювала умови для вирішення конфлікту у майбутньому на свою користь. Про це свідчить, насамперед, спрощення процедури надання російського громадянства мешканцям ОРДЛО, актуалізація на міжнародному рівні питань забезпечення прав національних меншин та інші дії.

Загалом, в інформаційному просторі розглядалось переважно два варіанти вирішення конфлікту:

виконання мінських угод, на чому наполягала РФ;

направлення до України поліцейської місії ОOH, на чому активніше за усіх наполягали США i Україна за певної підтримки Польщі.

Міжнародна спільнота очікувала головні зсуви у політиці України щодо вирішення конфлікту після обрання новим Президентом України В. Зеленського, який у передвиборчій програмі назвав припинення вогню і початок діалогу з РФ своєю пріоритетною задачею. За даними опитувань, більшість населення України виступала за припинення конфлікту [8], a експерти зазначали падіння антиросійських настроїв і навіть повернення на порядок денний теми євразійської інтеграції [9].

Після обрання нового Президенту України у липні 2019 року було досягнуто угоди про розведення сил у трьох місцях на лінії зіткнення. $\mathrm{He}$ дивлячись на певні обмеження в отриманні інформації зі сходу України, відкриті повідомлення ЗМІ свідчили про наявність внутрішніх сил, не згодних 3 позицією нового Президента України щодо скорішого припинення вогню i відведення озброєнь від лінії зіткнення. Такими силами виявились добровольчі батальйони і кілька організацій націоналістичного напряму, лідери яких відверто погрожували Президенту України багатомільйонними акціями протесту. За опитуваннями, позицію цих організацій підтримувало до $20 \%$ населення України, тобто відчутна його частина. Упродовж 2019 року ясно відчувалось, що ці організації мають досить серйозний вплив, а населення України залишається розколотим зсередини.

Одночасно в інформаційному просторі України почали 3'являтись думки, які кардинально відрізнялись від офіційної позиції колишнього вищого воєннополітичного керівництва державою. Найбільш яскравим прикладом можна назвати заяву відомого українського бізнесмена I. Коломийського, який назвав конфлікт на сході України громадянським конфліктом [10]. Були й інші подібні оцінки. С підстави припустити, що такі зміни у внутрішньому інформаційному просторі відбулися внаслідок впливу змін позицій впливових країн, хоча не можна впевнено стверджувати про єдність поглядів серед ї воєнно-політичного керівництва.

Особливо показовою у цьому відношенні була позиція США. 3 одного боку, у серпні Президент США заявив про необхідність угоди між президентами України i РФ. Але 3 іншого боку - тимчасовий повірений по справах США в Україні У. Тейлор заявив, що однією з головних задач нового Президента України є протидія РФ. Інший приклад надав помічник Держсекретаря США зі справ Свропи Д. Кент, який обвинуватив Адміністрацію Президента США в спробах обійти офіційну політику Держдепартаменту [11]. Є очевидним, що внутріполітична боротьба в США стала безпосередньо відбиватись на їх міжнародній політиці, зокрема, на ставленні до вирішення конфлікту на сході України. Це показала також затримка надання військової допомоги Україні 3 боку США, обвинувачення американських політиків в корупційних схемах в Україні та інші епізоди. Відсутність координованої щодо України політики змусила Президента США відсторонити від неї Держдепартамент i призначити відповідальним органом Адміністрацію 
Президента. Потім Держдепартамент взагалі усунув посаду свого представника в Україні.

Європейський Союз не був схильний афішувати свої дій щодо вирішення конфлікту на сході України, але в інформаційному просторі відчувалась поява підтримки позиції РФ (особливо з боку Франції [12]), зростання намірів завершити конфлікт на базі безумовного виконання Україною мінських угод, а також певний політичний тиск на керівництво України $з$ цього приводу. Тобто можна говорити про початкові ознаки тенденції на зближення позицій ЄС і РФ. Втім слід зазначити про наявність певних ознак нестійкості позиції $€ \mathrm{C}$, що свідчить про неоднозначність іï зміни. Головною з таких ознак стала підтримка України 3 боку центральних структур Єврокомісії у спробі скоригувати мінські домовленості, зокрема, змінити послідовність заходів - спочатку взяти під контроль України державний кордон з РФ і лише потім провести вибори в ОРДЛО.

Відбулися зміни у ставленні провідних воєнно-політичних сил щодо антиросійських санкцій. Їх головною особливістю було те, що ці санкції не спричинили втрат для американської економіки, але втрати європейської економіки оцінювались у досить значні суми, зокрема називалась цифра 100 млрд євро втрат німецького бізнесу за підрахунками профільного комітету бундестагу. Одночасно провідними політиками і США, і $€$ С визнавалась невелика ефективність санкцій щодо впливу на економіку РФ. Найяскравішим показником зміни ставлення щодо санкцій стало повернення делегації РФ до ПАРС 3 одночасним виключенням представників України 3 комітету по санкціях і ганебним офіційним поясненням - “невідповідність географічному балансу" [13]. Нові більшменш значущі санкції $6 C$ не запроваджувались. Навпаки, СС виводив 3-під дії санкцій окремих причетних до конфлікту фізичних осіб, а провідні країни $Є \mathrm{C}$ збільшували інвестиції в російську економіку. США вводили нові санкції, але їх характер більше натякав на використання санкцій не для вирішення конфлікту, а для вирішення питань міжнародної конкурентної боротьби на свою користь.

Про зміну ставлення до РФ 3 боку міжнародного співтовариства, особливо з боку $€ C$, свідчить також багато ознак вторинного характеру, зокрема:

обвинувачення України в неефективності економічної і соціальної політики, в корупції, зростанні радикальних націоналістичних настроїв у суспільстві, відсутності свободи слова;

збільшення кількості і обсягів контрактів на постачання російського озброєння;

фінансування 3 боку ЄC програм співробітництва 3 РФ, наприклад програми "Північний вимір", яка має геополітичний характер [14];

поступове зменшення публікацій в 3МI, де РФ називалась би агресором, а Україна розглядалась би як жертва;

зростання випадків відвідування Криму громадянами європейських країн.

Ще однією ознакою змін стала поява в інформаційному просторі думок щодо геополітичних причин розв'язування конфлікту, які раніше були неможливими в силу цензури і політичної доцільності. Яскравим прикладом була заява відомого німецького політолога О. Рара [15] стосовно Заходу, який у 2014 році на силове придушення тодішнім Президентом України акцій протесту і був готовий у цьому разі підтримати відокремлення Західної України.

Результатом змін позицій провідних воєнно-політичних сил стали розведення сил у кількох місцях на лінії зіткнення, обмін утримуваними i зустріч лідерів країнучасників норманського формата. Аналіз змісту інформаційних повідомлень також висвітлив певні проблеми, на яких надалі буде зосереджена увага у разі реалізації мінських угод у тому вигляді, у якому вони існують на сьогодні:

незгода України до погодження змін Конституції України 3 представниками самопроголошених республік;

неясність стосовно джерел ресурсів, потрібних для відновлення ОРДЛО;

необхідність (у разі реалізації мінських угод) виплат величезних коштів мешканцям ОРДЛО, які не виплачувались упродовж конфлікту i виплат, яких потребує моніторингова місія ООН зі справ людини;

обгрунтовані побоювання України щодо можливості “параду автономій” в регіонах у разі виконання мінських угод;

поява на сході України значної кількості громадян 3 російськими паспортами, які 3 високою впевненістю не підтримуватимуть конституційно закріплений курс України на європейську і євроатлантичну інтеграцію.

Зазначені проблеми мали місце в основі чисельних заяв, намагань i пропозицій політиків та посадових осіб України, які 
висловлювались перед зустріччю в норманському форматі у грудні 2019 року. Проте на цій зустрічі Україна не змогла погодити 3 іншими учасниками перегляд мінських угод на свою користь. Головною причиною стала непоступлива позиція РФ i прагнення ЄС понад усе завершити конфлікт.

Висновки. Загалом слід зазначити, що розстановка сил у 2019 році за проблемою вирішення конфлікту на сході України набуває ознак (хоча й нестійких) можливості зміни. Є підстави вважати, що США після окупації Криму з боку РФ і невдачі рішення щодо завдання РФ неприпустимих економічних збитків за допомогою санкцій втрачають інтерес до “українського питання” і нині намагаються використати його у власній внутрішньополітичній боротьбі. Можна припустити, що інтерес до України з боку США як головного союзника зменшуватиметься. ЄС на сьогодні зазнає відчутних збитків від економічних санкцій проти РФ в умовах економічної стагнації, яка посилюватиметься внаслідок фінансовоекономічної кризи і пандемії коронавірусу. Отже 3 часом неготовність СС нести збитки зростатиме. Це підштовхуватиме $\mathrm{EC} \mathrm{до}$ поліпшення стосунків 3 РФ, насамперед в енергетичній сфері та сфері торгівлі. РФ, не зважаючи на значні внутрішні соціальноекономічні проблеми, зайняла позицію очікування в конфлікті на сході України. РФ може тримати самопроголошені республіки у сфері свого впливу лише завдяки підтриманню рівня життя населення, трохи більшого за той, що забезпечується в Україні. Слід підкреслити, що зростаюча фінансовоекономічна нестабільність України може надавати воєнно-політичному керівництву РФ підстави для розрахунку на позитивне для себе вирішення питань, пов'язаних 3 конфліктом на сході України. РФ має можливість чекати на створення сприятливих умов для досягнення власних інтересів навіть у довгостроковій перспективі.

\section{ПЕРЕЛІК ВИКОРИСТАНОЇ ЛІТЕРАТУРИ}

1. S. Sveshnikov, V. Bocharnikov, V. Pavlenko. The Signs of Changes in the International Relations and Security in Europe. International scientific journal published under the auspices of NATO Defence Education Enhancement Program. January 2020. No 1/(12) 1. URL: https://www.sdirect24.org/kopianato-deep-no-11 (дата звернення: 03.03.2020).

2. Golden Sachs прогнозирует падение ВВП США на $34 \%$ и рост безработицы на $15 \%$. URL: https://comments.ua/news/money/economy/649748goldman-sachs-prognoziruet-padenie-vvp-ssha-na- 34-i-rost-bezraboticy-na-15.amp (дата звернення: 03.03.2020).

3. Куртсеітов Т. Л., Павлунько М. Я., Посмітюх О. I. Основні виклики та загрози Російській Федерації у військовій сфері: основа застосування піi збройних сил на південнозахідному стратегічному напрямку. Збірник наукових прачь Центру воєнно-стратегічних досліджень Національного університету оборони Украйни імені Івана Черняховського. Київ, 2019. № 3 (67). C. 23-27.

4. Зюзя О. В., Храпач Г. С. Дослідження російських геостратегічних цілей стосовно України через призму структурного аналізу збройного конфлікту на Донбасі. Збірник наукових працьь Центру воєнно-стратегічних досліджень Національного університету оборони Украӥни імені Івана Черняховського. Київ, 2019. № 3 (67). C. 130-135.

5. Украина не попала в приоритеты ООН на 2019 год. URL: https://korrespondent.net/world/4054602ukrayna-ne-popala-v-pryorytety-oon-na-2019-hod (дата звернення: 24.02.2020).

6. Разведка Франции: США лгали про российское вторжение на Украину. URL: https://nk.org.ua/geopolitika/razvedka-frantsii-sshalgali-pro-rossiiskoe-vtorzhenie-na-ukrainu-227986 (дата звернення: 24.02.2020).

7. У США показали фільм про вбивства на Майдані зі звинуваченнями на адресу Байдена та Обами. URL: https://pershij.com.ua/u-sshapokazaly-film-pro-vbyvstva-na-maidani-zizvynuvachenniamy-na-adresu-baidena-ta-obamy (дата звернення: 24.02.2020).

8. Ради мира $70 \%$ украинцев готовы на компромисс. URL: https://korrespondent.net/ ukraine/4064618-rady-myra-70-ukrayntsev-hotovyna-kompromyss (дата звернення: 25.02.2020).

9. Почти четверть украинцев до сих пор хотят в Таможенный союз. URL: https://www.pravda.com.ua/rus/news/2019/02/27/72 07871 (дата звернення: 25.02.2020).

10. Коломойский считает войну на Донбассе “гражданским конфликтом". URL: https://www.pravda.com.ua/rus/news/2019/05/2/721 4116 (дата звернення: 25.02.2020).

11. “Три амиго". Чиновник Госдепа рассказал об ответственной за политику в Украине команде Белого дома. URL: https://nv.ua/world/geopolitics/ belyy-dom-naznachil-komandu-otvetstvennuyu-zaukrainu-podrobnosti-50048115.html (дата звернення: 20.02.2020).

12. Макрон заявил о необходимости “ясного и прочного" диалога с Россией. URL: https://ovu.com.ua/news-28363-makron-zayavil-oneobhodimosti-yasnogo-i-prochnogo-dialoga-srossiej.html (дата звернення: 20.02.2020).

13. В ПАСЕ прокомментировали исключение Украины из комитета по снятию санкций. URL: https://regnum.ru/news/polit/2557163.html (дата звернення: 22.02.2020).

14. МИД: сотрудничество России и ЕС в рамках “Северного измерения" имеет хорошие 
перспективы. URL: https://tass.ru/politika/6189488 (дата звернення: 22.02.2020).

15. Трусость Януковича привела к отделению Крыма вместо потери Львова - немецкий эксперт. URL: https://kp.crimea.ua/2019/08/10/ trysost-ianykovicha-privela-k-otdeleniu-krymavmesto-poteri-lvova-nemeckii-ekspert (дата звернення: 03.03.2020).

Стаття надійшла до редакційно колегії 06.04.2020

\section{Analysis of regional military-political relations in the light of the resolution of the military conflict in eastern Ukraine}

\section{Annotation}

In 2020, the global financial and economic crisis intensified by the coronavirus pandemic began, the result of which can be expected not only to slow down regional economic development, but also to change the attitude of the leading powers towards solving the main military-political problem of Ukraine - the military conflict in its East. In 2020, only two resolution options were discussed in the information space: the implementation of the Minsk agreements (position of the Russian Federation) and the UN police mission (position of the United States, Ukraine and Poland). The Russian Federation has reduced information activity and today makes it clear that it has no intention of retreating from its own position. On the other hand, an analysis of military-political events indicates the appearance of signs of a possible change in the position of the western partners of Ukraine, the main of which was the exclusion from the UN priorities of resolving this conflict and its positioning as one from other frozen conflicts. In addition, there are signs of a transformation in assessments of socially significant resonant events, and the coordination of foreign policy regarding Ukraine is weakening. In the context of the economic crisis, the EU begins to look differently at economic sanctions against the Russian Federation, which bring considerable losses to the European economy. Ukraine failed to agree with other negotiators on the revision of the Minsk agreements in its favor. All this indicates an increase in the possibility of losing attention to the conflict in eastern Ukraine from the United States and the EU, and Ukraine should take this possibility into account when forming its own military policy.

Keywords: security environment; military-political situation; military-political relations; military policy; military conflict. 